\title{
Adenomas detected during screening colonoscopies in the years 2000-2009
}

\author{
Gruczolaki wykryte w trakcie kolonoskopii przesiewowej w latach 2000-2009
}

\author{
Maciej Świątkowski ${ }^{1}$, Agnieszka Meder ${ }^{1}$, Lesław Sobczyński ${ }^{1}$, Jarosław Koza ${ }^{1}$, Małgorzata Szamocka ${ }^{1}$, \\ Janina Brudny ${ }^{1}$, Jadwiga Korenkiewicz ${ }^{2}$ \\ 1Department of Gastroenterology, Vascular Diseases and Internal Diseases, Nicolaus Copernicus University, \\ Ludwik Rydygier Collegium Medicum, Bydgoszcz, Poland \\ 2Department of Patomorphology, Dr Jan Biziel University Hospital No. 2, Bydgoszcz, Poland
}

Prz Gastroenterol 2012; 7 (5): 299-305

DOI: $10.5114 / p g .2012 .32069$

Key words: adenomas, colon, screening colonoscopy.

Słowa kluczowe: gruczolaki, jelito grube, kolonoskopia przesiewowa.

\begin{abstract}
Address for correspondence: Prof. Maciej Świątkowski MD, PhD, Department of Gastroenterology, Vascular Diseases and Internal Diseases, Nicolaus Copernicus University, Ludwik Rydygier Collegium Medicum, 22/30 Karłowicza St, 85-092 Bydgoszcz, Poland, phone/fax: +48 5237149 12, e-mail: mswi@wp.pl
\end{abstract}

\begin{abstract}
Introduction: It is estimated that $95 \%$ of colorectal cancers (CRC) develop from adenomas. Currently, the most effective method of preventing colorectal cancers is by removing adenomas during a colonoscopy. The most effective and the cheapest way of increasing the 5 -year survival rate and curbing the constant increase in CRC incidence is through screening colonoscopies.

Aim: To analyze the adenomas detected during screening colonoscopies.

Material and methods: In Poland, the Screening Program for Early Colorectal Cancer Detection, the basic tool of which is a colonoscopy performed once every 10 years, has been carried out since 2000 . There were 1,442 screening colonoscopies performed in our center between 2000 and 2009.

Results: Polyps were found in $25.8 \%$ of the participants. Adenomas were found in $17.3 \%$ of the participants, including $14.2 \%$ of the women and $22.4 \%$ of the men. Histopathological evaluation performed after endoscopic polypectomy indicated tubular adenomas in 191 examined people. Seventy-one participants had serrated adenomas diagnosed. Ten people had tubulovillous, and one participant had villous adenoma. Advanced adenomas were detected in $2.7 \%$ of the women and $3.9 \%$ of the men.

Conclusions: Colonoscopy is an effective tool for detection, diagnosis, removal and qualification for further monitoring as regards the presence of adenomas. Adenomas are more often found in men, the inhabitants of rural areas, people whose first-degree relatives have had a malignant tumor in the abdomen, and those with diverticula found in the large intestine.
\end{abstract}

\section{Streszczenie}

Wstęp: Przyjmuje się, że 95\% raków jelita grubego (RJG) rozwija się na bazie gruczolaków. Obecnie najefektywniejszą metodą zapobiegania wystąpieniu RJG jest usuwanie gruczolaków w trakcie kolonoskopii. Najskuteczniejszym i najtańszym sposobem podwyższenia odsetka 5-letnich przeżyć i zahamowania stałego wzrostu zapadalności na RJG są kolonoskopie przesiewowe.

Cel: Analiza gruczolaków wykrytych w trakcie przesiewowej kolonoskopii.

Materiał i metody: W Polsce od 2000 roku realizowany jest Program Badań Przesiewowych dla wczesnego wykrywania raka jelita grubego (PBP), którego podstawowym narzędziem jest kolonoskopia wykonywana raz na 10 lat. W ośrodku autorów w ramach badań przesiewowych w latach 2000-2009 wykonano 1442 kolonoskopie przesiewowe.

Wyniki: Obecność polipów stwierdzono u $25,8 \%$ badanych. Wykazano obecność gruczolaków u 17,3\% osób, w tym u 14,2\% kobiet i 22,4\% mężczyzn. W badaniu histopatologicznym po endoskopowej polipektomii stwierdzono gruczolaki cewkowe u 191 badanych. Gruczolaki ząbkowane rozpoznano u 71 osób. Cewkowo-kosmkowy charakter utkania gruczolaka wykazano u 10 pacjentów. W jednym przypadku gruczolak miał utkanie kosmkowe. Gruczolaki zaawansowane wykryto u 2,7\% kobiet i u 3,9\% mężczyzn.

Wnioski: Kolonoskopia jest skutecznym narzędziem wykrywania, rozpoznawania, usuwania i kwalifikowania do dalszego nadzoru gruczolaków. Gruczolaki częściej wykrywa się u mężczyzn, mieszkańców obszarów wiejskich, osób obciążonych nowotworem złośliwym w obrębie jamy brzusznej u krewnych pierwszego stopnia, a także u osób, u których stwierdzono wspótistnienie uchyłków w jelicie grubym. 


\section{Introduction}

According to the classification of the World Health Organization, colorectal polyps are divided into epithelial and other types. Among epithelial polyps there are adenomas, which may be further divided into tubular, villous, tubulovillous, serrated adenomas and hyperplastic polyps. Among the other polyps, there are inflammatory, juvenile, Peutz-Jeghers, and non-epithelial polyps [1]. The theory of carcinogenesis in the large intestine as the process of adenomas changing into tumors has been acknowledged for several decades. It is estimated that $95 \%$ of colorectal cancers (CRC) develop from adenomas [2]. Therefore, from the clinical point of view, there are "advanced adenomas", characterized by a high cancer risk, among colorectal adenomas. We can talk about an "advanced adenoma" when an adenomatous polyp is formed and is characterized by one of the following features: it is larger than $1 \mathrm{~cm}$, has a villous component (villous or tubulovillous adenoma), dysplasia of a high degree is found or it has the structure of a cancer [3]. The characteristic feature of colorectal adenomas is their synchronous and metachronous occurrence. If one adenoma is detected, the risk of synchronous adenomas is $30-50 \%$ and of metachronous adenomas 20 $50 \%$. This phenomenon also applies to the synchronous and metachronous occurrence of adenomas and CRC [3]. The progression of colorectal adenoma into cancer takes many years, is composed of many stages and is often multifocal. Adverse changes in the genetic apparatus of a cell are modified, activated or curbed by numerous environmental factors, such as food, tobacco smoking and exposure to mutagenic substances. In normal conditions the proliferation of mucous membrane cells in the large intestine is regulated above all by the foods consumed. They may influence proliferation directly or by polyamines, hormones and growth factors, such as epidermal growth factor (EGF) or gastrin. Nutritional components have either a protective effect or quite the opposite, contributing directly or indirectly to the exposure of the mucous membrane cells of the large intestine to the activity of factors that damage DNA [4]. Chemoprevention consisting of using natural or synthetic chemical substances with the aim of reversing, curbing or preventing cancerous transformation of tissue is applied in the primary prevention of adenoma and CRC at the same time [5]. However, currently the most effective and recognized method throughout the world for preventing CRC is removing adenomas during colonoscopy. Consequently, the best way of increasing the five-year survival rate and curbing the constant increase in CRC incidence is through screening colonoscopy [6]. In 2000 the Nationwide Screening Program for Early Colorectal Cancer Detection was started on the initiative of the Oncology Institute in Warsaw and the Ministry of Health in Poland. It was also decided that screening colonoscopies performed once every ten years would be the tool used in that program. A screening colonoscopy is the best, the cheapest and the most effective way of carrying out screening tests. The fact that colonoscopies are much cheaper in Poland than in the Western countries also creates favorable conditions for using it as a screening test in our country. It allows not only the detection of early asymptomatic cancers, but also the removal of all colorectal polyps found [7]. Colorectal adenomas, which are recognized as a pre-cancerous stage, occur in around $25 \%$ of examined people aged 50 years and over [8]. Removing all adenomas during colonoscopy as well as monitoring patients properly after polypectomy and an operation for CRC at an early stage of progression results in a decrease in the risk of cancer by $76-90 \%$ in this group [9].

\section{Aim}

The aim of this paper was to analyze the adenomas detected during colonoscopies carried out as part of the Screening Program for Early Colorectal Cancer Detection in the period 2000-2009.

\section{Material and methods}

Screening colonoscopies financed by the national budget were carried out for Polish citizens aged 50-65 years and those aged 40-65 years with a history of abdominal malignant tumor in first-degree relatives. The presence of clinical symptoms suggesting CRC and advanced diseases resulting in generally poor patient condition were the health criteria for exclusion from the screening program. Participants with inflammatory bowel diseases and meeting the criteria for familial adenomatous polyposis or hereditary cancer unrelated to polyposis did not qualify for the screening either. One day before the examination patients took an agent based on polyethylene glycol for bowel preparation. The screening colonoscopy was performed under an anesthetic with the use of midazolam, which was administered orally 15 min before the examination. When describing the examination, the endoscopist evaluated the quality of the bowel preparation, any abnormalities encountered and the cecal intubation. The quality of the bowel preparation was assessed using the 4-degree scale proposed by the American Society of Gastrointestinal Endoscopy (ASGE) and the American College of Gastroenterology: very good, good, sufficient and poor cleansing [10]. During the screening colonoscopy, polyps of a size up to $1 \mathrm{~cm}$ were removed. The histopathological evaluation of the adenomas removed after polypectomy was based on the criteria defined by the World Health Organization. Polyps 
greater than $1 \mathrm{~cm}$ in diameter were removed during a separate hospitalization financed by the National Health Fund. Patients diagnosed with large intestinal cancers were sent to hospital for surgical treatment. After their colonoscopy the participants completed an anonymous questionnaire in which they expressed their opinion of the screening program.

\section{Statistical analysis}

Fisher's exact test was used for the statistical evaluation of the data. The value $p<0.05$ was assumed to be statistically significant.

\section{Results}

A total of 1,442 people took part in the study. Among the subjects, there were 883 women (61.2\%) and 559 men (38.8\%). The average age of the participants equaled 56.1 years. The average age of the women equaled 55.9 years and the men 56.6 years. Of the participants, $27.7 \%$ were aged $60-65$ years, $64 \%$ were aged 50-59 years and $8.3 \%$ were aged $40-49$ years. The most numerous group was composed of Bydgoszcz inhabitants (73\%), followed by inhabitants of other cities (14.5\%) and rural areas (12.5\%). Cancer located in the abdomen had been found in first-degree relatives in 485 cases (33.6\% of all participants), including 326 cases ( $22.6 \%$ of all participants) of large intestine cancer. A colonoscopy under anesthesia was performed in 1,240 (86\%) of the participants. The bowel preparation was very good in 774 cases $(53.7 \%)$, good in 462 cases $(32 \%)$, sufficient in 204 cases $(14.1 \%)$ and poor in 2 cases $(0.2 \%)$. Cecal intubation was performed

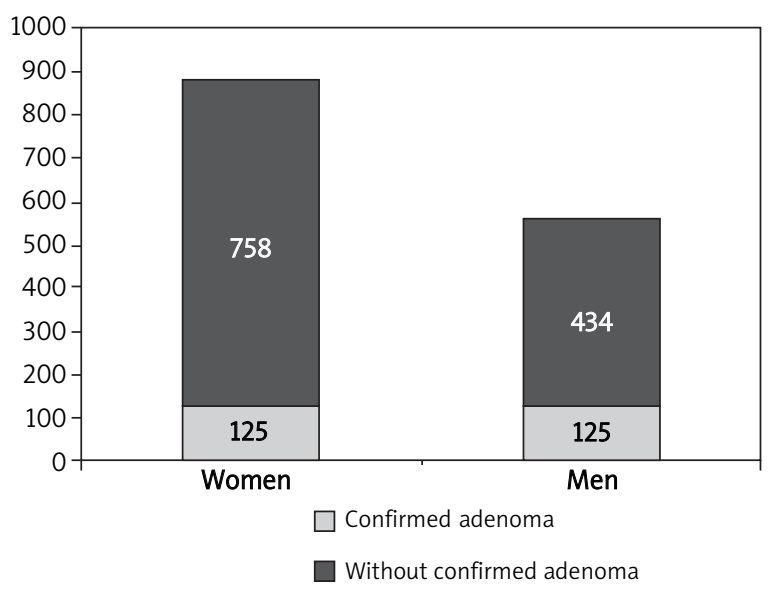

Fig. 1. Adenoma occurrence depending on participants' sex

Ryc. 1. Występowanie gruczolaków w zależności od ptci badanych in 1,330 subjects (92.2\%). During the colonoscopy, a polyp or polyps were detected in 373 patients $(25.8 \%)$. Moreover, in the endoscopic examination of the large intestine, 6 cases (0.42\%) of CRC and other abnormalities such as diverticula in 203 cases, endoscopic melanosis features in 44 cases and hemorrhoids in 445 cases were found.

Fisher's exact test was used to perform a simple statistical analysis of the data in the nominal scale with the aim of searching for relations between adenoma presence and potential factors that might determine a higher risk of their occurrence.

Based on the histopathological examination, it was demonstrated (Figure 1) that 250 patients (17.3\%) had adenomas completely removed by endoscopy, including those for 125 women (14.2\%) and 125 men (22.4\%) ( $p<0.0001)$; this method accounted for 191 tubular, 71 serrated, 10 tubulovillous and one villous adenoma. Adenomas meeting the criteria for "advanced adenoma" (Figure 2) were detected and removed in 46 people (3.2\% of the study group), including 24 women $(2.7 \%$ of all the women in the study group) and 22 men (3.9\% of all the men in the study group). These adenomas constituted $16.8 \%$ of all the adenomas detected in the study. In this group adenomas had the structure of cancer in five cases. Of the 1,442 participants, 1,434 answered questions posed in a questionnaire after their screening colonoscopy: 1,301 people (90.2\%) considered the preparation for the examination as not or a little bothersome, while 133 patients (9.8\%) expressed an opposite opinion. The tolerance for the screening colonoscopy was assessed as good or very good by 1,245 patients (86.3\%) and as bad by 44 patients (3.7\%). Figure 3 shows the frequency of adenoma incidence depending on the

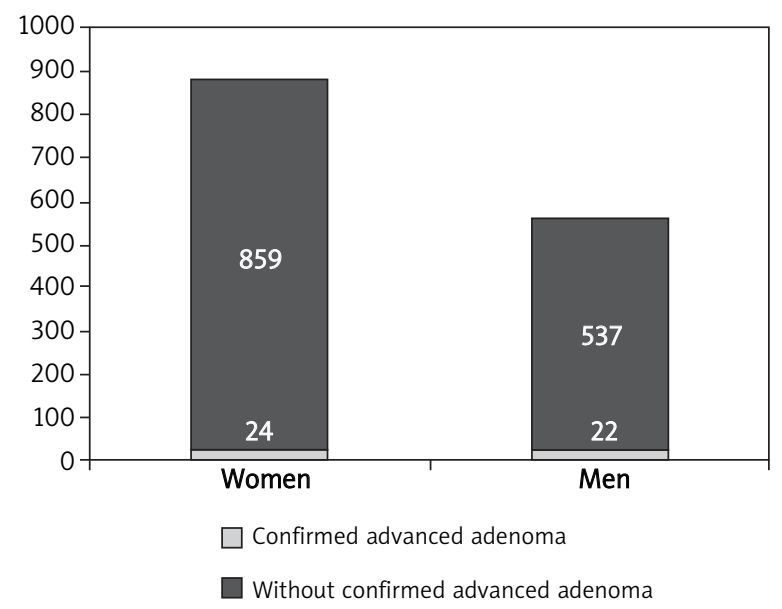

Fig. 2. Advanced adenoma occurrence depending on sex

Ryc. 2. Występowanie zaawansowanych gruczolaków w zależności od płci 
place of living. Adenomas were much more frequently found among inhabitants of rural areas (43; $23.9 \%)$ than among urban inhabitants $(207 ; 16.4 \%)(p=0.0155)$.

Figure 4 shows the results depending on the history of abdominal cancer in first-degree relatives. Adenomas were much more frequently detected in the group of patients with a history of abdominal cancers in firstdegree relatives $(62 ; 19.0 \%)$ compared with patients without such history $(138 ; 12.4 \%)(p=0.0034)$.

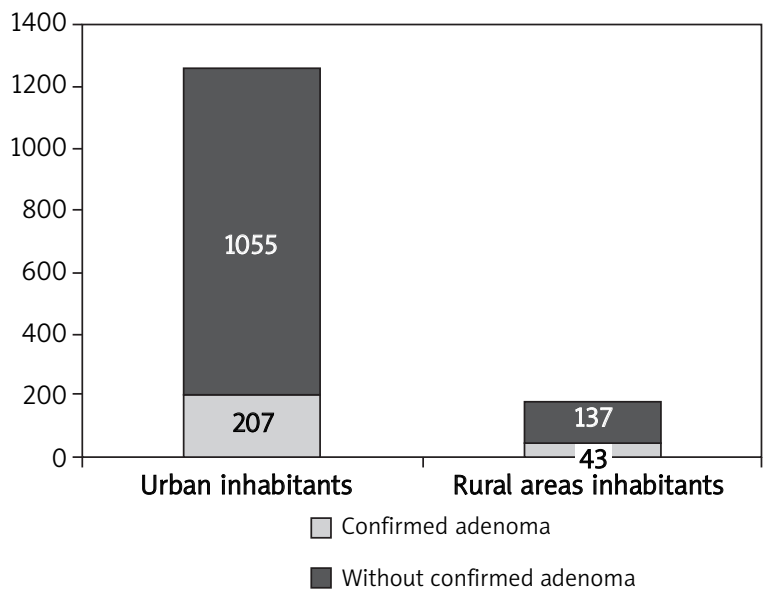

Fig. 3. Adenoma occurrence depending on the place of living

Ryc. 3. Występowanie gruczolaków w zależności od miejsca zamieszkania osób badanych

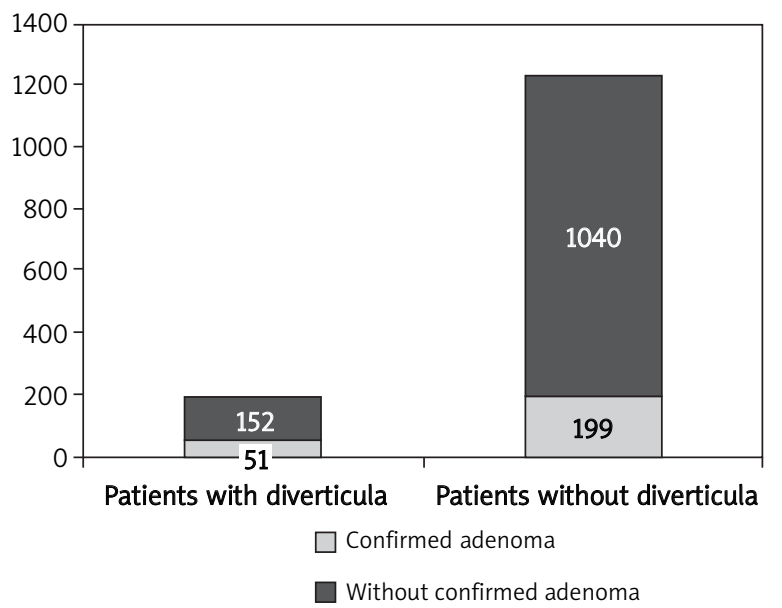

Fig. 5. Adenoma occurrence depending on the presence of diverticula

Ryc. 5. Występowanie gruczolaków w zależności od obecności uchytków jelita grubego
Figure 5 demonstrates results depending on the simultaneous presence of diverticula in the large intestine. Adenomas were much more frequently detected in the group of patients with diverticula $(51 ; 25.1 \%)$ compared with patients without such a burden (199; 16.1\%) ( $p=0.0026)$.

No statistical relation between the age groups was found (Figure 6). The statistical analysis of the obtained results demonstrates that the frequency of adenoma

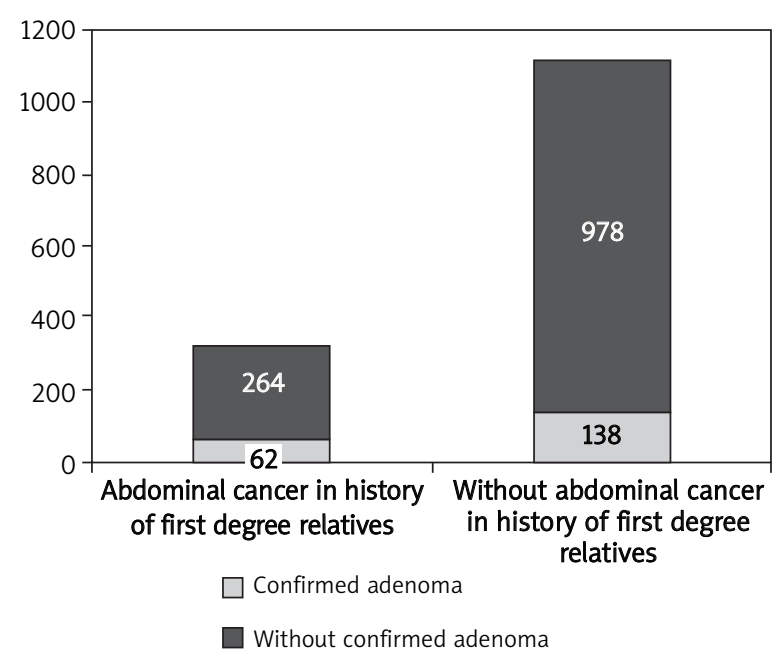

Fig. 4. Adenoma occurrence depending on the history of malignant abdominal tumors in firstdegree relatives

Ryc. 4. Występowanie gruczolaków w zależności od rodzinnego obciążenia nowotworami złośliwymi jamy brzusznej wśród krewnych pierwszego stopnia

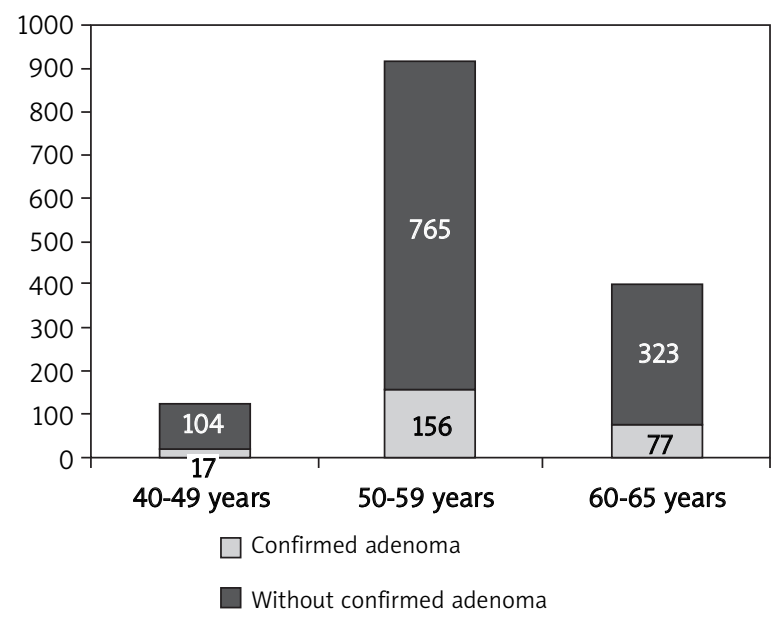

Fig. 6. Adenoma occurrence depending on the age of the participants

Ryc. 6. Występowanie gruczolaków w zależności od wieku osób badanych 
incidence does not depend on the age of the patients, the presence of melanosis features in the large intestine and the quality of the bowel preparation, or the degree to which the preparation for the examination is bothersome and the tolerance for the screening colonoscopy.

A further statistical evaluation was carried out to check if there were any relations between the particular potential risk factors of adenoma. Fisher's exact test was used to assess the independence. It was found that among all the analyzed factors there was a relation only between the age of patients and diverticula presence $(p<0.05)$ for people of 60 years old and older. Other factors were not related.

The data presented in Figure 7 also show no statistically significant difference in the localization of adenomas between the distal and proximal parts of the colon.

\section{Discussion}

In the Kujawsko-Pomorskie Province, where less than $5 \%$ of the population of Poland lives, 459 men and 386 women were diagnosed with CRC in 2008. Localization in the large intestine and rectum constituted $10.87 \%$ of all localizations of malignant tumors in the inhabitants of the region. Cancer of the large intestine is, after breast cancer, the second most frequent localization of malignant tumors among women (10.07\%) living in this region and the third among men (11.67\%) [11]. Although women more often undergo a screening colonoscopy, adenomas were statistically significantly more often found in men $[12,13]$. However, the difference does not ultimately translate into more cancer cases occurring in men compared to women. Most research results show that CRC occurs with the same frequency in men and women $[11,14]$. Our study also proves that although city inhabitants attend more often for screening colonoscopies than people from rural areas, adenomas were statistically significantly more often detected in the latter group [14]. This could be associated with the different eating habits of urban and rural populations, amongst other factors. The study suggests that in future more inhabitants of rural areas should be invited for a screening colonoscopy than have been until now. The majority of screening programs for the early detection of CRC using colonoscopy is aimed at people age 50 and over [9]. The "Polish" program is aimed at people aged $50-65$ years and also those aged $40-65$ years with a history of abdominal cancer in the family [7]. The results of our study show that there is no statistical difference in the frequency of adenomas detected in patients from the age groups of 40-49, 50-49 and 60-65 years. The fact that adenomas occur with a statistically similar frequency in patients with a history of abdominal cancer in the family aged $40-49$ yearscompared to

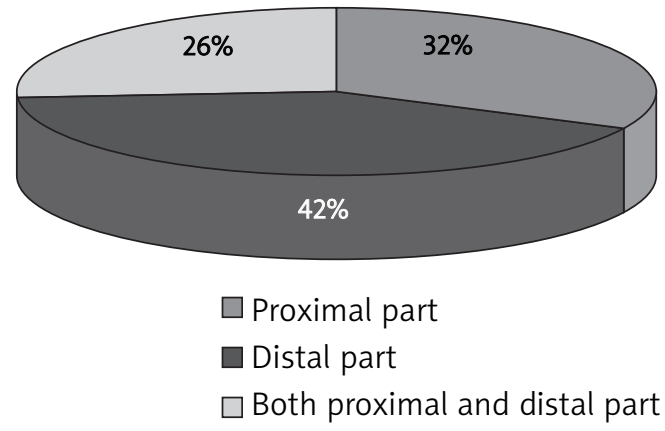

Fig. 7. Adenoma occurrence depending on the part of the large intestine under consideration Ryc. 7. Występowanie gruczolaków w zależności od odcinka jelita grubego

patients aged 50 years and over proves that screening tests should be started earlier in that age group and with such a medical history in the family in order to increase the 5-year survival rate and curb the constant increase in CRC incidence. Adenomas were detected in a significantly greater number of patients from the group of 485 participants with first-degree relatives who had died from cancer of the abdomen, including CRC, compared to the group without that burden [15]. The majority of CRC developing from adenomas are sporadic cancers (50-60\%), the development of which is influenced by poor diet, while in $30-45 \%$ of cases the socalled "familial aggregation of CRC" is found with no signs of particular mutations but with only the occurrence of that cancer in the family [16]. Diverticulum of the large intestine is a disease of civilization; its frequency increases with age and the duration of following a low-fiber diet. Constipation accompanying the disease increases the time of exposure of the mucous membrane to carcinogens. In our study there were many more patients with adenomas among patients with diverticula than among the others [17]. The group of 46 patients with "advanced adenomas" selected among the participants of the screening program and completed with other patients who met the criteria for being at "high risk" of CRC will be monitored using endoscopy, the first aim of which is to obtain the condition from just after the previous colonoscopy, i.e. the complete removal of all the changes in the large intestine after thorough examination [18]. A further recommendation for these patients is setting the date of the next colonoscopy. The aim of all these activities is, amongst others, to avoid the occurrence of interval cancer and to recognize and remove metachronous changes [19]. The results from our study show that neither large intestine melanosis connected with the chronic and common use 
of natural laxatives that contain anthranoid compounds nor hemorrhoidal disease are related to the frequency of large intestine cancer [20]. The frequency of adenoma detection is a very important parameter of the screening colonoscopy quality. The quality of bowel preparation has a large influence on the value of that parameter. The results of our study indicate that the frequency of adenoma detection in patients with very good, good and sufficient cleansing does not differ at a statistically significant level. That result may indirectly reflect the precision and high level of skill of the endoscopists performing screening colonoscopies [21, 22]. In our opinion, the quality of endoscopies may be improved by the skillful application of a water pump to wash away the feces from the area of the large intestine currently under observation. The degree to which the preparation for screening colonoscopies is connected with taking an agent based on polyethylene glycol and also the tolerance for the examination itself had no influence on the frequency of adenoma detection [7, 14]. For many years, the phenomenon of polyp proximalization has been observed in the large intestine. The results of our study agree with that opinion, as the frequency of adenomas detected in the rectum and sigmoid colon did not statistically differ from those in the colon and cecum. A high percentage of simultaneous adenoma detection in the distal and proximal parts of the large intestine during screening colonoscopies is similar to the results of other studies that confirm the risk of their synchronous occurrence [23].

\section{Conclusions}

Screening colonoscopies are an effective tool for detection, diagnosis, removal and qualification for further monitoring of pre-cancerous conditions such as colorectal adenomas. Colorectal adenomas are more often found in the following: men, the inhabitants of rural areas, people whose first-degree relatives have had a malignant tumor in the abdomen, and people with diverticula in the large intestine. The frequency of adenoma detection does not depend on the following: the quality of bowel preparation, the degree to which the preparation for the examination is bothersome, colonoscopy tolerance, the simultaneous presence of large intestine melanosis, hemorrhoidal disease, the localization of adenomas in the intestine, and belonging to the age groups of 40-49, 50-59 and 60-65 years among those with a history of abdominal cancer in first-degree relatives.

\section{Acknowledgments}

The Screening Program for Early Colorectal Cancer Detection was funded by the Polish Ministry of Health.

\section{References}

1. Hamilton SR, Aaltonen LA (eds). World Health Organisation Classification of Tumours. Pathology and Genetics of Tumours of the Digestive Tract. IARC Press, Lyon 2000; 104.

2. Potter JD, Slattery ML, Bostic RM. Colon cancer: a review of the epidemiology. Epidemiol Rev 1993; 15: 499-545.

3. Winawer S, Fletcher R, Rex D, et al. Colorectal cancer screening and surveillance: clinical quidelines and rationale-update based on new evidence. Gastroenteology 2003; 12: 544-60.

4. Kotynia J, Małecka-Panas E. Chemoprewencja raka jelita grubego. Gastroenterol Pol 2006; 13(1): 53-8.

5. Janne P, Mayer R. Chemoprevention of colorectal cancer. N Engl J Med 2000; 348: 879-80.

6. Levin B, Liberman DA, McFarland B, et al. Screening and surveillance for the early detection of colorectal cancer and adenomatous polyps, 2008: a joint quideline from the American Cancer Society, the US Multi-Society Task Force on Colorectal Cancer, and the American College of Radiology. Gastroenterology 2008; 134: 1570-95.

7. Reguła J, Rupiński M, Kraszewska E, et al. Colonoscopy in colorectal-cancer screening for detection of advanced neoplasia. N Engl J Med 2006; 366: 1863-72.

8. Rex DK, Johnson DA, Lieberman DA, et al. Colorectal cancer prevention 2000. Screening recommendations of the American College of Gastroenterology. Am J Gastroenterol 2000; 95 : 868-77.

9. Winawer SJ, Zauber AG, Ho MN, et al. Prevention of colorectal cancer by colonoscopic polypectomy. The National Study Polyp Workgroup. N Engl J Med 1993; 329: 1977-81.

10. Rex DK, Petrini JL, Baron TH, et al. Quality of indicators for colonoscopy. Am J Gastroenterol 2006; 101: 873-85.

11. Mierzwa T, Windorbska W, Turczyn B, et al. Zachorowania na nowotwory złośliwe w województwie kujawsko-pomorskim w roku 2008. Regionalne Centrum Onkologii im. prof. F. Łukaszczyka w Bydgoszczy, 2010.

12. Altenhofen L, Londong W. Interim results of preventive colonoscopy in Germany - a Nationwide colorectal cancer screening program. Gastroenterol Pol, 2010; 17 Suppl 1: 14.

13. Landis SH, Murray T, Bolden S, et al. Cancer statistics 1998. CA Cancer J Clin 1998; 48: 6-29.

14. Homa K, Safranow K, Brzosko M, et al. The evaluation of usefulness and tolerance of screening colonoscopy programmes in relation to selected demographic factors. Gastroenterol Pol 2005; 12: 499-503.

15. Winawer SJ, Zauber AG, Gerdes H, et al. Risk of colorectal cancer in the families of patients with adenomatous polyps. N Engl J Med 1994; 331: 1669-74.

16. Fuchs CS, Giovannucci EL, Golditz CA. A prospective study of family history and the risk of colorectal cancer. N Engl J Med 1996; 334: 82-7.

17. Solecki R, Szura M, Zając A, et al. Czy choroba uchyłkowa zwiększa ryzyko rozwoju raka jelita grubego? Analiza retrospektywna. Gastroenterol Pol 2010; 17 Suppl 1: 14.

18. Winawer SJ, Zauber AG, Fletcher RH, et al. Quidelines for colonoscopy surveillance after polypectomy. A consensus update by US Multi-Society Task Force on colorectal cancer. The American Cancer Society. Gastroenterology 2006; 355: 1863-72. 
19. Kamiński MF, Reguła J, Kraszewska E, et al. Quality indicators for colonoscopy and the risk of interval cancer. N Engl J Med 2010; 363: 1795-803.

20. Stępka M, Biernacka D, Górnicka B, et al. Is sigmorectal melanosis associated with neoplasia? Gastroenterol Pol 2006; 13: 85-8.

21. Wretowska D, Pracki M, Kamiński MF. Przygotowanie jelita grubego do kolonoskopii. Gastroenterol Klin 2010; 2: 30-6.

22. Kotowski B, Kamiński MF, Rupiński M, et al. Analiza jakości kolonoskopii w Ogólnopolskim Programie Badań Przesiewowych dla Wczesnego Wykrywania Raka Jelita Grubego. Gastroenterol Klin 2009; 1: 45-53.

23. Gil A, Romantowski JA, Killar G, et al. Proksymalizacja polipów gruczołowych i gruczolakoraka jelita grubego na terenie północno-wschodniej Polski. Gastroenterol Pol 2010; 17 Suppl 1: 12. 